УДК 330.341.1:656.2

\title{
УПРАВЛІННЯ ЗАБЕЗПЕЧЕННЯМ ЕКОНОМІЧНОЇ БЕЗПЕКИ РЕГІОНАЛЬНОЇ ФІЛІЇ АТ «УКРАЇНСЬКА ЗАЛІЗНИЦЯ»
}

\author{
Назаренко І.Л., к.е.н., доцент, \\ Межанова А.К., студентка магістратури, \\ Отченаш Ю.О., студент махістратури (УкрДУЗТ)
}

В статті розроблено схему функиіонування системи забезпечення ЕБ фрілї АТ «Украйнська залізниия» (за моделлю «чорний ящик») та виявлено, на які функиіональні складові впливають основні внутрішні загрози економічній безпеці АT «УЗ» та ї регіональних філій.

Виконано розрахунки рівня економічної безпеки регіональної філії «Південна залізничя» у 2014 - 2018 рр. і виявлені причини знаходження його у зоні ризику.

Ключові слова: управління забезпеченням економічної безпеки залізниці; оцінка рівня економічної безпеки залізниці; система забезпечення економічної безпеки залізниці; загрози економічної безпеки залізниці

\section{УПРАВЛЕНИЕ ОБЕСПЕЧЕНИЕМ ЭКОНОМИЧЕСКОЙ БЕЗОПАСНОСТИ РЕГИОНАЛЬНОГО ФИЛИАЛА АО "УКРАИНСКАЯ ЖЕЛЕЗНАЯ ДОРОГА"}

\author{
Назаренко И.Л., к.э.н., доцент, \\ Межсанова А.К., студентка магистратуры, \\ Отченаи Ю.А., студент магистратуры (УкрГУЖТ)
}

В статье разработана схема функиионирования системы обеспечения ЭБ филиала АO «Украинская железная дорога» (по модели «черный ящик») и выявлено, на какие функциональные составляющие влияют основные внутренние угрозы экономической безопасности $A O$ «УЗ» и ее региональных филиалов.

Выполнень расчеты уровня экономической безопасности регионального филиала «Южная железная дорога» в 2014 - 2018 г2. и выявлены причины нахождения его в зоне риска.

Ключевые слова: управление обеспечением экономической безопасности жселезной дороги; оценка уровня экономической безопасности железной дороги; система обеспечения экономической безопасности жселезной дороги; угрозы экономической безопасности железной дороги

\section{ECONOMIC SECURITY MANAGEMENT OF A REGIONAL BRANCH OF PUBLIC JOINT STOCK COMPANY "UKRAINIAN RAILWAY"}

\author{
Nazarenko I.L., PhD (economics), associate professor, \\ Mezhanova A., master students, \\ Otchenash Y., master students (USURT)
}

Ukrainian railway transport makes significant impact on the economy of Ukraine (56,1\% of freight turnover and 27,4\% of passenger traffic in 2018), as well as on such 
important components of its national security as economic security, political security, social security, military security and others. JSC «Ukrainian Railways» includes 6 regional affiliates (Southern Railway, Lviv railway and others), which are not legal entities, but have their own management systems and resourses.

The scheme of the economic security system for a regional affiliate of JSC «Ukrainian Railways" is developed in the paper (according to the black box model). Its inputs are: Threats to the economic security of JSC "Ukrainian Railways» (external and internal); Resources for economic security provision (personnel, financial, material, informational, etc). Its outputs are: an acceptable level of economic security of a regional affiliate (not lower than 0,80); sustainable development of a regional affiliate. Inside subsystems are named after 7 functional components of economic security provision: financial; intellectual and personnel; technical and technological; political and legal; informational; ecological; power.

The control subsystem of the scheme of the economic security system must include: a unit of diagnostics of level of economic security; a threat monitoring unit; a unit of organization, planning, motivation and control. The functions of the units are described in the paper.

It is also revealed what functional components of the economic security of JSC "UZ" and its affiliates are affected by major internal threats. The main internal threats are corruption, unprofessional leadership, the loss of skilled workers, the progressive depreciation of fixed assets and the distortion of reporting.

The calculations of the level of economic security of the regional affiliate "Southern Railway» in 2014 - 2018 are performed and the reasons for being it in the risk zone are revealed.

They are: low labour productivity, reduction of current liquidity and productivity of locomotive, low productivity of carriage, deepening of unprofitableness of activity of the railway (rate of return dropped to $-27,4 \%$ ).

Keywords: management of ensuring economic security of the railway; assessment of the economic security level of a railway; system for ensuring economic security of the railway; threats to the economic security of the railway

Постановка проблеми. АТ «Укрзалізниця» має визначну значимість для суспільної стабільності: це ключовий актив для забезпечення мобільності населення і єдності держави (...); це найбільший працедавець в Україні - 272 тис. робітників (і понад 400 тис. членів їх сімей), або $1,5 \%$ від усіх зайнятих [1]. I найголовніше - залізничний транспорт має значний вплив на економіку України (виконав 56,1\% вантажообігу та 27,4\% пасажирообігу у 2018 р.), а також на такі важливі складові їі національної безпеки, як економічна, політична, соціальна, військова та інші. Виключне значення залізничного транспорту ще посилюється в умовах проведення бойових дій на території нашої держави.

$\begin{array}{crr}\text { Оскільки } & \text { економічна } & \text { безпека } \\ \text { транспорту } & \text { визначається } & \text { його }\end{array}$

спроможністю якісно забезпечувати попит економічних суб'єктів на внутрішні та міжнародні перевезення; конкурувати на ринках міжнародних перевезень; ефективно реалізовувати транзитний потенціал, забезпечення економічної безпеки (ЕБ) залізничного транспорту - це питання не тільки галузевого, а й загальнодержавного значення.

Тому актуальним $\epsilon$ дослідження управління забезпеченням економічною безпекою АТ «Українська залізниця» та іiі регіональних філій.

Аналіз останніх досліджень i публікацій. Дослідженням економічної безпеки залізничного транспорту присвячені праці вітчизняних та зарубіжних науковців, зокрема Г.Д. Ейтутіса, Р.А. Кожевнікова, 3.П. Межох, Н.П. Терьошиної, Д.І. Ковальова, Т.Г. 
Сухорукової,

Плєтникової

В.Л. Диканя,

(Назаренко),

І.Л.

T.O.

Тимофєєвої, А.В. Толстової, Ж.С. Костюк та інших учених [2 - 10]. В їх працях розглядається сутність, складові економічної безпеки залізничного транспорту, розроблені методики їі оцінювання.

Не залишилося поза увагою вчених створення системи економічної безпеки підприємства та залізничного транспорту. Так, концептуальні засади створення та функціонування системи ЕБ підприємства досліджено в працях таких учених, як Г.В. Козаченко, О.М. Ляшенко, С.Н. Ілляшенко, П.Я. Пригунов, Б.С. Дуб [11], C.M. Шинкар [12] та інших учених, принципи та властивості системи забезпечення ЕБ підприємства окреслені в статтях В.M. Павліченка [13, 14]. Стосовно системи забезпечення ЕБ залізничного транспорту - зокрема А.Ю. Чередниченко запропонував систему забезпечення ЕБ підприємств залізничного транспорту [15]; загальна концепція, властивості та завдання системи забезпечення економічної безпеки регіональної філії «Південна залізниця» розроблені у статті [16].

$\begin{array}{cc}\text { Виділення } & \text { недосліджених } \\ \text { аспектів проблеми. } & \text { Але, дотепер }\end{array}$
проблемі розроблення системи управління забезпеченням економічної безпеки регіональних філій АТ «Українська залізниця» в науковій літератури не приділено достатньо уваги, що i обумовило вибір теми дослідження.

Тому метою даної статті $\epsilon$ розробка системи управління забезпеченням економічної безпеки регіональних філій АТ «Українська залізниця» (на прикладі регіональної філії «Південна залізниця»).

\section{Виклад основного матеріалу дослідження.}

Економічна безпека підприсмства це стан захищеності діяльності підприємства від всіх видів загроз, як зовнішніх, так і внутрішніх; стан, при якому забезпечується стабільне функціонування і прогресивний розвиток підприємства, досягається шляхом максимального ефективного використання наявних ресурсів і швидкої адаптації до умов середовища, що змінюється [5]. Дане визначення повною мірою відноситься і до економічної безпеки АТ «Українська залізниця» як великого підприємства юридичної особи.

Як визначено нами у [16], система забезпечення ЕБ залізниці - це сукупність взаємопов'язаних елементів (органів, засобів, методів і заходів), що діє на основі певних принципів, та спрямована на захист всіх функціональних складових економічної безпеки залізниці та іiі життєво важливих інтересів (як сфери інтересів АТ «Українська залізниця») від зовнішніх та внутрішніх загроз та мінімізації їх негативного впливу для забезпечення успішного фінансовоекономічного розвитку. Забезпечення ЕБ залізниці включає комплекс видів діяльності за функціональними складовими ЕБ залізниці: це фінансова; інтелектуальна і кадрова; технікотехнологічна; політико-правова; інформаційна; екологічна; силова.

Представимо управління системою забезпечення ЕБ регіональної філії АТ «Українська залізниця» у загальному схематичному виді (рис. 1).

Згідно 3 загальною схемою функціонування системи, виділено окремо систему, що підлягає управлінню (система забезпечення ЕБ філії АТ «Українська залізниця») та керуючу підсистему, яка це управління виробляс. Для вироблення управління потрібне передбачення його наслідків, тобто потрібна модель усієї ситуації. За допомогою цієї моделі визначається, яке управління подати на вхід у систему, тому схема зображена усередині керуючої підсистеми. 


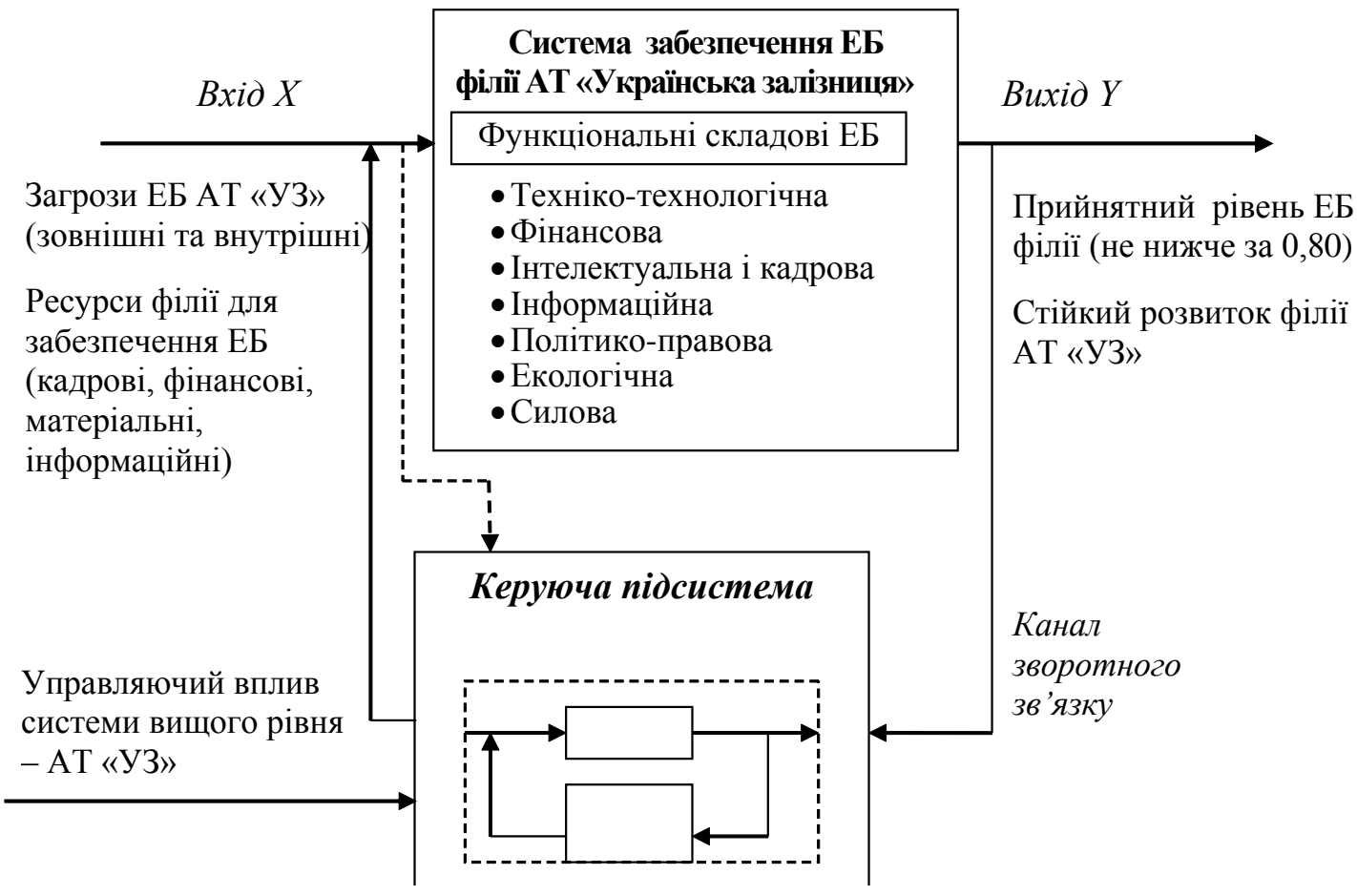

Рис. 1. Схема функціонування системи забезпечення ЕБ філії АТ «Українська залізнищя» (за моделлю «чорний ящиик»)

На нашу думку, керуюча назви та згідно 3 затвердженими підсистема повинна включати:

- блок діагностики рівня ЕБ;

- блок моніторингу загроз;

начальником Служби економічної безпеки програмами, планами і процедурами. Блок моніторингу загроз повинен
бути присутнім у керуючій підсистемі

- блок організації, планування, мотивації і контролю.

Всі ці блоки повинні бути втілені в Службі економічної безпеки, структура та функції якої запропоновані у [6] (звісно, 3 урахуванням сучасних змін у структурі управління регіональної філії).

Зокрема, блок діагностики рівня ЕБ повинен забезпечувати виконання розрахунків інтегрального показника ЕБ регіональної філії за методикою [5, 6]; визначення зони, в якій знаходиться показник (ідеальної безпеки; високої безпеки; прийнятної безпеки; зона ризику; зона загрози катастрофи); аналіз причин зміни локальних показників та розроблення пропозицій по їх покращенню.

Завдання блоку організації, планування, мотивації i контролю здійснювати функції відповідно до своєї виходячи 3 таких міркувань. По-перше, інтегральний показник рівня ЕБ відображає його зміну постфактум, коли вона вже відбулася, а для попередження загроз необхідний їх моніторинг. Подруге, багато загроз носять потенційний характер або є тимчасовими і можуть не відображатися у поточному рівні ЕБ, але, незважаючи на це, їм повинна бути приділена увага. Функція цього блоку виявлення максимально повного переліку загроз для їх попередження та нейтралізації.

Зупинимося більш детально на виявленні загроз економічній безпеці.

Цьому питанню зокрема присвячена стаття М.М. Чеховської [17]; виробничі загрози ЕБ підприємств залізничного транспорту визначені в роботі П.В. Лапіна

Вісник економіки транспорту і промисловості № 67, 2019 
[18]; в статті [19] виявлено основні загрози ЕБ локомотивного депо в процесі реформування галузі. В.В. Шемаєв розробив класифікацію загроз ЕБ [20]: реальні та потенційні; керовані та некеровані; одноразові, систематичні та періодичні; актуальні та перспективні; постійні та тимчасові тощо.

$\mathrm{He}$ претендуючи на повноту виявлення загроз, окреслимо тільки найважливіші внутрішні загрози (як ті, на які АТ «УЗ» може вплинути), які відносяться за класифікацією [20, с. 80-81] до реальних, керованих, актуальних, постійних, та визначимо, на які складові ЕБ АТ «УЗ» та їі філій в теперішній час вони чинять (можуть чинити) найруйнівнішу дію (див. рис. 2).

Найбільш небезпечні внутрішні загрози ЕБ АТ «УЗ» (та іiі філій)

Функціональні складові економічної безпеки

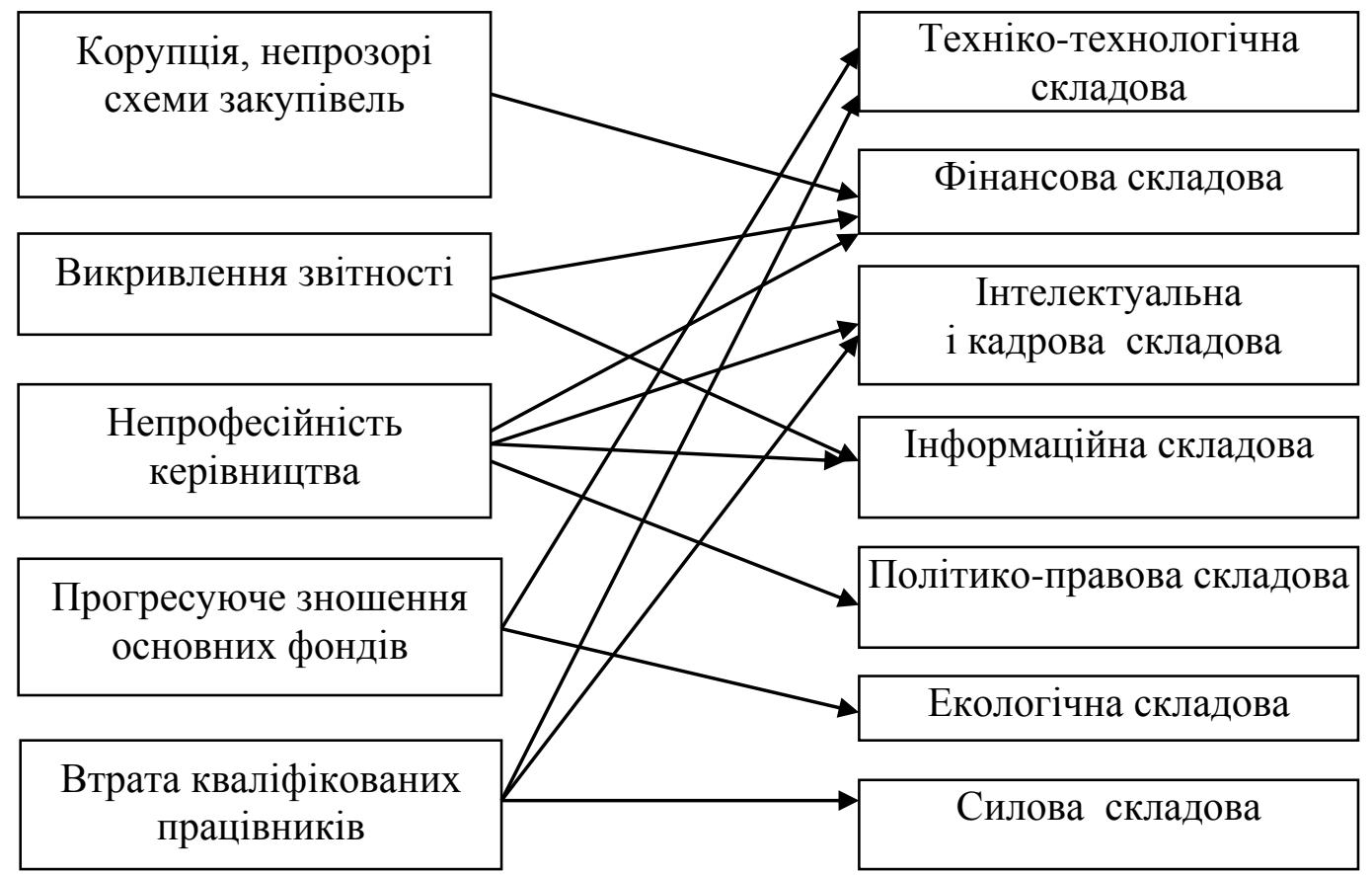

Рис. 2 - Схема впливу найважсливіших внутрішніх загроз на функціональні складові економічної безпеки $A T$ «УЗ» та ї̈ регіональних філій

Таким чином, саме попередженню $\mathrm{i}$ ліквідації цих загроз необхідно приділяти найбільшу увагу при забезпеченні ЕБ АТ «УЗ» та регіональних філій.

Стосовно загрози викривлення звітності - це, наприклад, проявилося у різкій зміні коефіцієнта зносу і, відповідно, коефіцієнта придатності основних виробничих фондів і може спотворювати оцінку рівня економічної безпеки (див. табл. $1)$.

Колосальне зростання коефіцієнта придатності основних фондів - 30,008 до
0,905 у 2015 році обумовлено переоцінкою основних засобів у 2015 році у зв'язку 3 формуванням ПАТ «Українська залізниця», i не викликано реальним оновленням фондів. Тією ж причиною обумовлений і стрибок фондовіддачі у 2015 році. Вважаємо, що такі зміни «на папері» не зміцнюють ЕБ залізничного транспорту, а навпаки, лише спотворюють звітність і породжують нові, інформаційні загрози економічній безпеці. Тому у розрахунках ми використали перераховані, не викривлені дані. 
Локальні показники ЕБ регіональної філії «Південна залізничя» та рівень ЕБ, розрахований за методикою [5, 6]

\begin{tabular}{|l|c|c|c|c|c|}
\hline Найменування показника & 2014 & 2015 & 2016 & 2017 & 2018 \\
\hline $\begin{array}{l}\text { 1 Продуктивність праці, тис. прив. ткм /1 } \\
\text { люд. }\end{array}$ & 961,7 & 1029,8 & 1000,6 & 1036,7 & 1063,9 \\
\hline $\begin{array}{l}\text { 2 Середньодобова продуктивність } \\
\text { вантажного вагона, ткм нетто }\end{array}$ & 3752 & 3587 & 4052 & 3781 & 3253 \\
\hline $\begin{array}{l}\text { 3 Середньодобова продуктивність } \\
\text { локомотива, тис. т-км брутто }\end{array}$ & 1650 & 1631 & 1683 & 1620 & 1127 \\
\hline 4 Коефіцієнт придатності ОВФ & 0,008 & 0,905 & 0,872 & 0,838 & 0,810 \\
\hline $\begin{array}{l}\text { 5 Фондовіддача основних виробничих } \\
\text { фондів (по залишковій вартості), грн } \\
\text { /грн }\end{array}$ & 0,013 & 1,004 & 0,933 & 0,331 & 0,314 \\
\hline $\begin{array}{l}\text { 6 Рентабельність виробничо-фінансової } \\
\text { діяльності, \% }\end{array}$ & 1,5 & 0,4 & $-8,9$ & $-21,3$ & $-27,4$ \\
\hline 7 Коефіцієнт поточної ліквідності & 0,3611 & 0,1347 & 0,0244 & 0,0191 & 0,0184 \\
\hline Інтегральний показник - рівень ЕБ & 0,131 & 0,322 & 0,228 & 0,226 & 0,104 \\
\hline
\end{tabular}

Згідно з визначеними у [6] зонами економічної безпеки, протягом аналізованого періоду рівень ЕБ знаходиться у зоні ризику (від 0,0 до 0,8 ), i знизився в основному під впливом таких негативних чинників: низької продуктивності праці (незважаючи на іiі деяке зростання) та продуктивності вагона, зменшення поточної ліквідності, значного зменшення продуктивності локомотива (через зростання коефіцієнта допоміжного пробігу з 0,14 у 2017 р. до 0,27 у 2018 р.) та колосального поглиблення збитковості виробничофінансової діяльності. Це вимагає не разових заходів, а цілеспрямованого систематичного управління забезпеченням економічної безпеки за допомогою відповідної системи.

\section{Висновки i перспективи} подальших досліджень. В статті розроблено схему функціонування системи забезпечення ЕБ філії АТ «Українська залізниця» (за моделлю «чорний ящик»). Зокрема, iї керуюча підсистема повинна включати блок діагностики рівня ЕБ; блок моніторингу загроз та блок організації, планування, мотивації i контролю, які повинні бути втілені в Службі економічної безпеки. Окреслені функції цих блоків.
Також виявлено, на які функціональні складові економічної безпеки АТ «УЗ» та іï філій впливають основні внутрішні загрози. Основними внутрішніми загрозами вважаємо корупцію, непрофесійне керівництво, втрату кваліфікованих працівників, прогресуюче зношення основних фондів та викривлення звітності.

Виконано розрахунки рівня економічної безпеки Південної залізниці у 2014 - 2018 pp. і виявлені причини знаходження його у зоні ризику.

Напрямками подальших досліджень може бути розробка організаційно-економічного механізму управління забезпеченням економічної безпеки АТ «УЗ» та його регіональних філій.

\section{ПЕРЕЛІК ВИКОРИСТАНИХ ДЖЕРЕЛ}

1. Основні аспекти стратегії розвитку ПАТ «Укрзалізниця». 2017-2021 роки [Електронний ресурс]. - Режим доступу: http://www.uz.gov.ua/files/file/ Strategy_Presentation_fin1.pdf.

2 Экономическая безопасность железнодорожного транспорта: учебник для вузов ж.-д. транспорта / Р.А.

Вісник економіки транспорту і промисловості № 67, 2019 
Кожевников, 3.П. Межох, Н.П. Терешина и др. - М.: Маршрут, 2005. - 326 с.

3 Ейтутіс Г. Оцінка економічної безпеки залізничного транспорту / Г. Ейтутіс // Економіст. - 2009. - №1.- С. 5659.

4 Ковалев Д.И., Экономическая безопасность предприятия / Д.И. Ковалев, Т.Г Сухорукова. // Экономика Украины. 1998- Вип. 11.- С. 48-52.

5 Ковальов Д.І. Кількісна оцінка рівня економічної безпеки підприємства / Д.І. Ковальов, І.Л. Плєтникова // Економіка України. - 2001. - Вип. 4. - С. $35-40$.

6 Плєтникова І.Л. (Назаренко І.Л.). Визначення рівня i забезпечення економічної безпеки залізниці: дис. ... канд.екон. наук: спец. 08.07.04 Економіка транспорту i зв'язку. Хар. держ. акад. залізн. трансп. - Х., 2001. $234 \mathrm{c}$.

7 Тимофєєва Т. О. Розробка механізму щодо забезпечення економічної безпеки залізничного транспорту: автореф. дис. ... канд.екон. наук : спец. 08.00.03 "Економіка та управління національним господарством"/ Т. О. Тимофєєва; Укр. держ. акад. залізн. трансп. - Х., 2009. - 20 с.

8 Дикань В.Л. Комплексна методика визначення рівня економічної безпеки, оцінки ризиків та ймовірності банкрутства підприємства: монографія / В.Л. Дикань, І.Л. Назаренко. - Харків: УкрДАЗТ, 2010. - 142 с.

9 Толстова А. В. Залізничний комплекс України як основа економічної безпеки країни / А.В. Толстова // Вісник економіки транспорту і промисловості. Вип. 37.- 2012. - С. 75-78.

10 Костюк Ж.С. Сутність поняття «Економічна безпека підприємств залізничного транспорту» / Ж.С. Костюк // Вісник економіки транспорту i промисловості. - 2013. - Вип. 41. - С. 173179.

11 Дуб. Б.С. Система економічної безпеки підприємства: поняття та структура [Електронний ресурс] /Б.С. Дуб.
Режим доступу:

https://cyberleninka.ru/article/n/sistema-

ekonomichnoyi-bezpeki-pidpriemstva-

12 Шинкар С. М. Система економічної безпеки підприємства: методичні засади формування / С. М. Шинкар // Причорноморські економічні студії. - 2018. - Вип. 25. - С. 133-137.

13 Павліченко В. М. Принципи функціонування системи забезпечення економічної безпеки підприємства / В. М. Павліченко // Вісник економіки транспорту і промисловості. - 2015. - Вип. 51. - C. 39-44.

14 Павліченко В. М. Визначення основних властивостей системи забезпечення економічної безпеки підприємства / В. М. Павліченко // Вісник економіки транспорту і промисловості. 2015. - Вип. 50. - С. 254-258.

15 Чередниченко А.Ю. Система экономической безопасности предприятий железнодорожного транспорта /А.Ю. Чередниченко // Вісник економіки транспорту і промисловості. - 2015. Вип. 51.-- С. $67-72$.

16 Назаренко I. Л. Система забезпечення економічної безпеки регіональної філії "Південна залізниця" / І. Л. Назаренко, Т. О. Голованова // Вісник економіки транспорту і промисловості. 2018. - Вип. 64. - С. 241-248.

17 Чеховська M.M. Загрози економічній безпеці підприємств залізничного транспорту у виробничій сфері / М.М. Чеховська // Науковий вісник Херсонського державного університету. 2014. - Серія: Економічні науки. - Вип. 91. - Частина 3. - С. 119-122.

18 Лапін П. В. Виробничі загрози економічній безпеці підприємств залізничного транспорту / П. В. Лапін // Вісник економіки транспорту i промисловості. - Вип.55. - 2016. - С. 41-50

19 Назаренко І. Л. Забезпечення економічної безпеки локомотивного депо в умовах реформування галузі / І. Л. Назаренко, Т. Г. Сухорукова, Н. Кірія // Вісник економіки транспорту i промисловості. - 2015. - Вип. 52. - С. 114- 
120.

20 Шемаєв В.В. Управління розвитком транспортної інфраструктури в системі економічної безпеки держави дис. ... д-ра екон. наук: спец. 21.04.01. економічна безпека держави (економічні науки)/ В.В. Шемаєв. Національний інститут стратегічних досліджень, Київ, 2018. - 494 c.

\section{REFERENCES}

1.Osnovni aspekty strateghiji rozvytku PAT «Ukrzaliznycja». 2017-2021 roky. [Main aspects of the development strategy of PJSC "Ukrzaliznytsya". 20172021.]. Available at: http://www.uz.gov.ua /files/file/Strategy_Presentation_fin1.pdf. (accessed 14 May 2018).

2.Kozhevnykov R.A., Mezhokh Z.P., Tereshyna N.P. y dr. (2005). Ekonomicheskaia bezopasnost zheleznodorozhnogo transporta: uchebnik dlia vuzov zh.-d. transporta [Economic safety of railway transport: a textbook for high schools. of transport]. Moscow: Marshrut. P.326.

3.Ejtutis Gh. (2009) Ocinka ekonomichnoji bezpeky zaliznychnogho transport. [Assessment of the economic security of railway transport]. Economist, vol. 1 , pp $56-59$.

4 Kovalev D.I., Sukhorukova T.Gh. (1998) Ekonomicheskaia bezopasnost predpriiatiia. [Economic security of the enterprise]. Economy of Ukraine, vol. 11, pp. 48-52.

5 Kovaljov D.I., Plietnukova I.L.(2001) Kiljkisna ocinka rivnja ekonomichnoji bezpeky pidpryjemstva. [Quantitative assessment of the economic security level of an enterprise]. Economy of Ukraine, vol. 4, pp. 35-40.

6. Plietnukova I.L. (Nazarenko I.L.) (2001) Vyznachennja rivnja i zabezpechennja ekonomichnoji bezpeky zaliznyci. [Determining the level and ensuring the economic security of the railway]. (PhD Thesis). Kharkiv, Ukrainian State University of Railway Transport.
7. Tymofjejeva T. O. (2009) Rozrobka mekhanizmu shhodo zabezpechennja
ekonomichnoji bezpeky zaliznychnogho transport. [Development of a mechanism for ensuring the economic safety of railway transport]. ( $\mathrm{PhD}$ Thesis). Kharkiv, Ukrainian State University of Railway Transport.

8. Dykan V.L., Nazarenko I.L. (2010) Kompleksna metodyka vyznachennja rivnja ekonomichnoji bezpeky, ocinky ryzykiv ta jmovirnosti bankrutstva pidpryjemstva. (Monograph) [Complex methodology for determining the level of economic security, risk assessment and bankruptcy probability of the enterprise]. Kharkiv, Ukrainian State University of Railway Transport. - P. 142.

9. Tolstova A. V. (2012) Zaliznychnyj kompleks Ukrajiny jak osnova ekonomichnoji bezpeky krajiny. [Railway complex of Ukraine as the basis of economic security of the country]. Bulletin of Economics of Transport and Industry, vol. 37, pp. 75-78.

10. Kostjuk Zh.S. (2013) Sutnistj ponjattja «Ekonomichna bezpeka pidpryjemstv zaliznychnogho transportu». [The essence of the concept "Economic security of railway enterprises"]. Bulletin of Economics of Transport and Industry, vol.. 41, pp. 173-179.

11 Dub. B.S. (2016) Systema ekonomichnoji bezpeky pidpryjemstva: ponjattja ta struktura. [Enterprise economic security system: concept and structure]. Available at: https://cyberleninka.ru/article /n/sistema-ekonomichnoyi-bezpeki-

pidpriemstva (accessed 10 October 2019).

12. Shynkar S. M. (2018) Systema ekonomichnoji bezpeky pidpryjemstva: metodychni zasady formuvannja. [System of economic security of the enterprise: methodical principles of formation]. Black Sea Economic Studies, vol. 25, pp. 133-137.

13. Pavlichenko V. M. (2015). Pryncypy funkcionuvannja systemy zabezpechennja ekonomichnoji bezpeky pidpryjemstva. [Principles of functioning of the enterprise economic security system]. Bulletin of Economics of Transport and Industry, vol. 51, pp. 39-44.

Вісник економіки транспорту і промисловості № 67, 2019 
14. Pavlichenko V. M. (2015). Vyznachennja osnovnykh vlastyvostej systemy zabezpechennja ekonomichnoji bezpeky pidpryjemstva. [Determination of the basic properties of the system of ensuring the economic security of the enterprise]. Bulletin of Economics of Transport and Industry, vol. 50, pp. 254-258.

15. Cherednichenko A.Yu.(2015). Sistema ekonomicheskoy bezopasnosti predpriyatiy zheleznodorozhnogo transporta [System of economic security of railway enterprises]. Bulletin of Economics of Transport and Industry, vol. 51, pp. 67-72.

16. Nazarenko I.L.(2018) Systema zabezpechennja ekonomichnoji bezpeky reghionaljnoji filiji "Pivdenna zaliznycja". [System of economic security of the regional branch "Southern Railway"]. Bulletin of Economics of Transport and Industry, vol. 64, pp. 241-248.

17. Chekhovsjka M.M. (2014) Zaghrozy ekonomichnij bezpeci pidpryjemstv zaliznychnogho transportu u vyrobnychij. [Threats to the economic security of railway undertakings in the production sector]. Scientific Bulletin of Kherson State University, vol. 9-1, part 3, pp. 119-122.

18. Lapin P. V. (2016) Vyrobnychi zaghrozy ekonomichnij bezpeci pidpryjemstv zaliznychnogho transportu. [Production threats to the economic security of railway undertakings]. Bulletin of Economics of Transport and Industry, vol. 55, pp. 41-50.

19. Nazarenko I. L., Sukhorukova T.H., Kiriya N. (2015) Zabezpechennja ekonomichnoji bezpeky lokomotyvnogho depo $\mathrm{v}$ umovakh reformuvannja ghaluzi. [Ensuring the economic security of the locomotive depot in the context of industry reform]. Bulletin of Economics of Transport and Industry, vol. 52, pp. 114-120.

20. Shemaiev V.V. Upravlinnja rozvytkom transportnoji infrastruktury $\mathrm{v}$ systemi ekonomichnoji bezpeky derzhavy [Management of development of transport infrastructure in the system of economic security of the state]. (Doctor Thesis). Kyiv, Nacionaljnyj instytut strateghichnykh doslidzhenj.

УДК 330.142: 656.2

\title{
СИСТЕМА УПРАВЛІННЯ ІНТЕЛЕКТУАЛЬНИМ КАПІТАЛОМ СТРУКТУРНИХ ПІДРОЗДІЛІВ ЗАЛІЗНИЧНОГО ТРАНСПОРТУ (НА ПРИКЛАДІ МОТОРВАГОННОГО ДЕПО)
}

\author{
Назаренко І.Л., к.е.н., доцент, \\ Ужсивий Д.В., студент магістратури (УкрДУЗТ)
}

В статті розроблена система управління інтелектуальним капіталом структурного підрозділу залізничного транспорту (на прикладі Лиманського моторвагонного депо), впровадження якої дозволить підвищити ефективність формування і використання інтелектуального капіталу.

Виконано розрахунки за матеріалами Лиманського депо за 2017 - 2018 роки, проаналізовано причини зміни величини його інтелектуального капіталу. Запропоновано створення робочої групи з ращіоналізащії та визначено ї̈ місие у структурі депо та функиї підрозділів.

Ключові слова: інтелектуальний капітал, система управління, моторвагонне депо, залізничний транспорт, людський капітал.

(C) Назаренко І.Л., Уживий Д.В.
Вісник економіки транспорту і промисловості № 67, 2019 